\title{
“Acta Haematologica Polonica” awarded 100 points by Ministry of Education and Science!
}

\author{
Jan Styczyński ${ }^{*}$ (D), Agata Marjańska (D) \\ Department of Pediatric Hematology and Oncology, Collegium Medicum in Bydgoszcz, Nicolaus Copernicus University in Toruń, \\ Jurasz University Hospital 1, Bydgoszcz, Poland
}

Ministry of Education and Science (MEiN, Ministerstwo Edukacji i Nauki) awarded our journal with 100 points for parametrization [1]. This has ranked "Acta Haematologica Polonica" among the most prestigious Polish journals.

"Acta Haematologica Polonica" was created in 1970, being the journal of Polish Society of Haematologists and Transfusiologists and Insitute of Haematology and Transfusion Medicine [2]. The journal being 52 years old is the most important and influential journal in the field of Polish hematology and transfusion medicine [3]. The journal covers all aspects of hematology, presented by Polish and international scientists. From two years all papers in the journal are published exclusively in English. From current year the journal is published bimonthly [4]. A number of papers prepared by international groups were published in "Acta Haematologica Polonica" [5, 6]. Authors from Western Europe and America as well as all over the world have coauthored papers published in the journal. The rejection rate in 2021 reached 30\%. Still, the chances for PubMed and impact factor depends on citation papers published in "Acta Haematologica Polonica" in recent two calendar years in international journals. It can be done only by entire society!

\section{Conflict of interest}

Nothing to disclose.

Financial support

No financial support.

\section{Authors' contributions}

Both authors contributed equally to the paper.

\section{References}

1. Komunikat Ministra Edukacji i Nauki z dnia 1 grudnia 2021 r. w sprawie wykazu czasopism naukowych i recenzowanych materiałów z konferencji międzynarodowych. https://www gov pl/web/edukacja-i-nauka/ komunikat-ministra-edukacji-i-nauki-z-dnia-1-grudnia-2021-r-w-sprawie-wykazu-czasopism-naukowych-i-recenzowanych-materialow-z (December 1, 2021).

2. Styczynski J. 50 years of ogica onica: value of vaccinations in patients with hematological disorders. Acta Haematol Pol. 2019; 50(4): 181, doi: 10.2478/ahp-2019-0029.

3. Giebel S, Basak G, Bieniaszewska M, et al. Current status and progress of Polish hemato-oncology. Acta Haematol Pol. 2021; 52(1): 4-17, doi: 10.5603/AHP.2021.0002.

4. Styczyński J. "Acta Haematologica Polonica": on its new road. Acta Haematol Pol. 2021; 52(1): 1, doi: 10.5603/AHP.2021.0001.

5. Czyżewski K, Sedláček P, Štěrba J, et al. Progress and trends in pediatric hematopoietic cell transplantation in Central-East European countries. Acta Haematol Pol. 2020; 51(3): 142-150, doi: 10.2478/ ahp-2020-0026.

6. Styczynski J, Tridello G, Gil L, et al. Prognostic impact of Epstein-Barr virus serostatus in patients with nonmalignant hematological disorders undergoing allogeneic hematopoietic cell transplantation: the study of Infectious Diseases Working Party of the European Society for Blood and Marrow Transplantation. Acta Haematol Pol. 2020; 51(2): 73-80, doi: 10.2478/ahp-2020-0015.

\footnotetext{
*Address for correspondence: Jan Styczyński, Department of Pediatric Hematology and Oncology, Collegium Medicum, Nicolaus Copernicus University Toruń, Skłodowskiej-Curie 9, 85-094 Bydgoszcz, Poland, phone +48525854860, fax +48 5258540 87, e-mail: jstyczynski@cm.umk.pl Received: 5.11.2021 Accepted: 5.11.2021
}
PTHiT Copyright (๑) 2021 The Polish Society of Haematologists and Transfusiologists, Insitute of Haematology and Transfusion Medicine. All rights reserved. articles and share them with others as long as they credit the authors and the publisher, but without permission to change them in any way or use them commercially. 